\title{
Effects of Different Seed Density, Temperature and Fertilization Applications on Some Growth Parameters in Soilless Roll Sod Production
}

\section{Muhammet KARAŞAHIN ${ }^{* 1}$ \\ ${ }^{1}$ Selcuk University Cumra School of Applied Sciences, Department of Organic Agriculture Management, Çumra/Konya/Turkey}

\begin{abstract}
This study was conducted to determine the effects of different seed density, temperature, and fertilization applications on some growth parameters in the soilless roll sod production. When research results are evaluated by taking into account the highest overall appearance and green plant yield values together, it is observed that $75 \mathrm{~g} \mathrm{~m}^{-2}$ seed density and 25 and $30^{\circ} \mathrm{C}$ temperature applications are in recommendable qualification. For future research to be conducted on the subject, it is considered useful to include different growing times and land applications in the studies.
\end{abstract}

Keywords: Fertilization, temperature, seed density, soilless roll sod

Topraksız Rulo Çim Üretiminde Farklı Tohum Miktarı, Sıcaklık ve Gübreleme Uygulamalarının Bazı Gelişim Parametreleri Üzerine Etkileri

Öz: Bu çalışma farklı tohum miktarı, sıcaklık ve gübreleme uygulamalarının topraksız rulo çim üretiminde bazı gelişim parametreleri üzerine etkilerinin belirlenmesi amacıyla yapılmıştır. Araştırma sonuçları en yüksek genel görünüm ve yeşil bitki verimi değerleri birlikte dikkate alınarak değerlendirildiğinde $75 \mathrm{~g} \mathrm{~m}^{-2}$ tohum miktarı ile 25 ve $30^{\circ} \mathrm{C}$ sıcaklık uygulamaları tavsiye edilebilir niteliktedir. Konu ile ilgili ileride yapılacak araştırmalarda farkı yetiştirme süreleri ve arazi uygulamalarının da çalışmalara dahil edilmesi yararlı görülmektedir.

Anahtar Kelimeler: Gübreleme, sıcaklık, tohum miktarı, topraksız rulo çim

\section{INTRODUCTION}

Grass areas have important functions in eliminating the negative effects of stressful urban life. For this reason, it is also required to increase green areas in parallel with the rapidly growing urban population (Avcıoğlu, 1997). Grass areas are defined as horizontally established green area surfaces, where there are usually plant or plant communities that cover the soil surface, grow in a dense way, have a homogeneous appearance, usually took place in the Gramineae family, and are constantly mowed and kept in a certain size (Orçun, 1979).

The roll sod is a grass form created by cutting the grass with its roots from the land and wrapping it in rolls like a carpet and making it ready to be laid on another area; the grass used here is the grass that was previously planted in the soil and whose root development was ensured by mowing several times and caring (Karaşahin, 2020). Since ready roll sods are available for sale as ready-to-use (grown and strengthened previously), installation of them is easy. As long as there is no frost in the soil, roll sod can be laid down. Roll sod integrates with its new ground within 10-15 days. Roll sod production is carried out either by planting directly on agricultural soil or by adding a small amount of turf on the soil. As the fertile upper soil layer in a $4-5 \mathrm{~cm}$ thickness is removed from the area along with the grass after each harvest, a kind of soil erosion is caused. To compensate for this loss, the soil is brought from other places occasionally and laid on the area; however, in this way, soil losses are also experienced in other areas.

Washed roll sod is obtained by separating the harvested roll sod from the soil by means of water jets while it is proceeding on the conveyor belt (Turgeon, 2002). It provides significant advantages, especially in the installation of golf and sports fields and in the repair of damaged areas. However, the production of washed roll sod is quite expensive, and it is quite difficult to completely remove the soil from the roots (Casimate et al., 1993). In the production of washed roll sod, time is lost with postharvest washing. This time creates a problem in adaptation, especially in hot times. As there is no soil left in both ultimately, washed roll sod and soilless roll sod come across as mixable terms. In the production of washed roll sod, after the grass grown in the environment that have soil is harvested together with soil, the soil is removed from the grass by washing; on the other hand, the production of soilless roll sod is carried out on impermeable layers using various substrate materials other than the soil. Because soilless roll sod production is performed by using biodegradable substrate material on impermeable sheets such as plastic, grass roots are not cut during harvest. Thus, the grass roots are integrated with the soil in a shorter time in the area where it is applied. Since soil is not used in production, the soil laying costs are eliminated. In the production of soilless roll sod, artificial organic fiber materials can be used as substrate materials (Karaşahin,

*Corresponding Author: mkarasahin@selcuk.edu.tr. This research was financially supported by the Scientific Research Project of Selçuk University (Project Number: 17401185).

The submitted date: September 16, 2020

The accepted date: February 17, 2021 
2020). Since grass roots are not plucked or cut at harvest periods, they are not damaged at all. Whereas grass roots expend serious energy by going to deep in the production done with soil, they use the majority of their energy on the production of green parts in the soilless roll sod production. Thus, the time required to be ready for sale is getting considerably shorter. Another advantage of it is the ability to be harvested in the desired sizes. In addition, in winter conditions, such production can be easily done in a greenhouse environment. In this way, it creates an opportunity for the installation of sports fields in the early spring. Conventional roll sod production is completely dependent on environmental conditions. Today, highquality grass is demanded every season in the installation and repair of sports fields and golf courses (Karaşahin, 2020).

Due to the fact that grass plant seeds are quite small, planting directly into the soil reduces the chances of success. For this reason, to guarantee the emergence of them after planting and to obtain a uniform and straight emergence, the soil should be improved in terms of some properties such as soil structure, the amount of organic matter, plant nutrient sufficiency, soil water holding capacity, and soil permeability.

Since planting is usually done by hand, it is quite difficult and important to spread equal amounts of seeds into the unit area. If the seed amount to be spread to the unit area is less than $20 \mathrm{~g} \mathrm{~m}^{-2}$, the covering rate of seeds reduces considerably; If it is more than $40 \mathrm{~g} \mathrm{~m}^{-2}$, since plants start competing, they remain skinny and root diseases are seen quite common (Kuşvuran, 2009).

It was seen that high seed amounts had a positive effect on grass quality at the beginning, while in later periods it decreased grass quality due to inter-plant competition. It was also found that there was a problem in terms of fighting weeds when a low amount of seed was used, while in planting performed using a moderate amount of seed, better grass quality was achieved after the installation. Avcıoğlu (1997) stated that cool-climate Gramineae grasses need $10-18{ }^{\circ} \mathrm{C}$ for root growth and $15-25{ }^{\circ} \mathrm{C}$ for aboveground growth and development.

Among the most important factors affecting the growth and development of grass are temperature, humidity, light, weather conditions, and geography (Alshammary et al., 2004; Carrow et al., 2010). Since the climate can change over the years, there are different recommendations for the growth, form, and cultivation of grass. A good grass area installation usually requires 10 to 18 months of time, depending on climatic conditions (Carrow et al., 2001).

Grass areas need more nutrients than other cultivated plants since they are constantly mowed and watered. 42
Because a large amount of leaf formation is demanded in these areas, fertilization is very important (Özad, 2010).

Nitrogen has a positive effect on many different characteristics of grass plants, such as the shoot density, color, resistance to diseases, and regeneration ability. Color is often used as an indicator in the nitrogen fertilization. Therefore, the amount and application time of nitrogen fertilization play an important role in the maintenance of grass areas (Oral and Açıkgöz, 1999; Salman and Avcıoğlu, 2010).

In this study, it was aimed to determine the effects of different seed density, temperature, and fertilization applications on soilless roll sod.

\section{MATERIALS AND METHODS}

The research was carried out in the hydroponics production field at Selcuk University, Cumra School of Applied Sciences (Figure 1). $33 \times 11.5 \mathrm{~cm}$ aluminum frames were used as the cultivation setting (Figure 2).

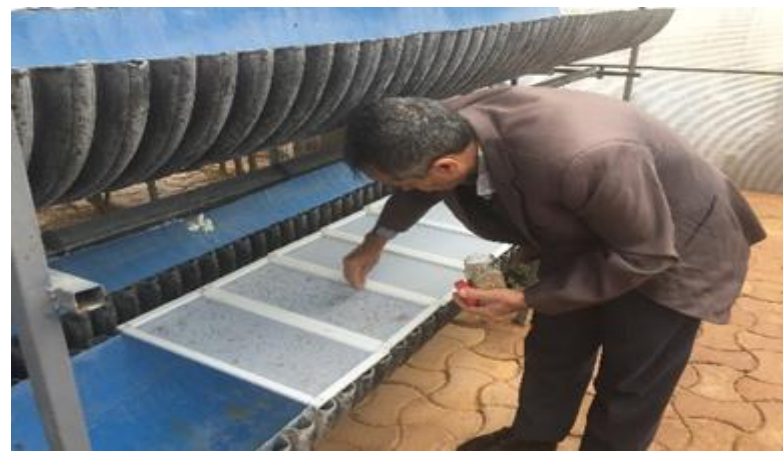

Figure 1. Hydroponics production field

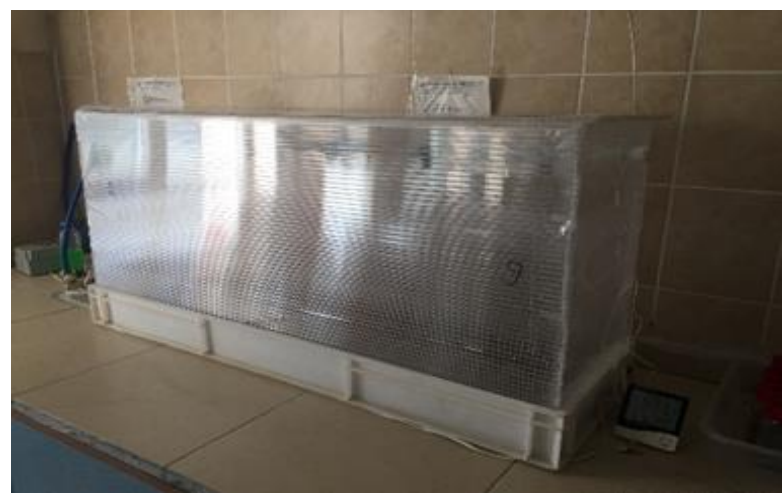

Figure 2. Cultivation setting

In the study, $50 \mathrm{~g} \mathrm{~m}^{-2}$ was applied as seed density, $20{ }^{\circ} \mathrm{C}$ as ambient temperature, control as growing medium and fertilizer source, cotton fiber as the substrate material, sprinkler as irrigation method $\left(20 \mathrm{sec} 6 \mathrm{~h}^{-1}\right)$, and 15 days as cultivation period. Only the parameters investigated have been changed in each application. In the irrigation system, the city water supply network was used as the water source (Table 1). 
Table 1. Properties of the irrigation water

\begin{tabular}{lccc}
\hline \multicolumn{2}{c}{ Properties $\left(\mathrm{mg} \mathrm{l}^{-1}\right)$} & \multicolumn{2}{c}{ Properties $\left(\mathrm{mg} \mathrm{l}^{-1}\right)$} \\
\hline $\mathrm{pH}$ & 7.19 & $\mathrm{Zn}$ & 0.94 \\
$\mathrm{EC}\left(\mathrm{mS} \mathrm{cm}^{-1}\right)$ & 0.615 & $\mathrm{P}$ & 0.20 \\
$\mathrm{NO}_{3}\left(\mathrm{mg} \mathrm{l}^{-1}\right)$ & 3.22 & $\mathrm{~K}$ & 0.03 \\
$\mathrm{Ca}\left(\mathrm{mg} \mathrm{l}^{-1}\right)$ & 150.12 & $\mathrm{~B}$ & 0.13 \\
$\mathrm{Mg}\left(\mathrm{mg} \mathrm{l}^{-1}\right)$ & 10.7 & $\mathrm{Mn}$ & 0.02 \\
$\mathrm{Na}\left(\mathrm{mg} \mathrm{l}^{-1}\right)$ & 2.93 & $\mathrm{Cu}$ & 0.02 \\
\hline
\end{tabular}

In the research, perennial ryegrass (Lolium perenne L.) was used as the plant material.

In order to determine the effects of different seed density $\left(25,50\right.$ and $\left.75 \mathrm{~g} \mathrm{~m}^{2-1}\right)$, temperature $\left(20,25\right.$ and $\left.30^{\circ} \mathrm{C}\right)$, and fertilization (Co: control, Sw: seaweed, and In: inorganic) applications on soilless roll sod, the following characteristics were examined: green plant yield $\left(\mathrm{g} \mathrm{m}^{2}{ }^{-1}\right)$, dry matter rate $(\%)$, dry grass yield $\left(\mathrm{g} \mathrm{m}^{2}\right)$, plant height $(\mathrm{mm})$, emergence speed (day), covering speed (day), root length (cm), overall appearance (1-9), shoot diameter $(\mathrm{mm})$, tiller number (number $\mathrm{cm}^{2-1}$ ), leaf blade length $(\mathrm{cm})$, leaf blade width $(\mathrm{mm})$ and the index value (leaf blade length/leaf blade width).

In different fertilization (control, seaweed, and inorganic) applications, mains water was used as control. In seaweed application, $370 \mathrm{ppm}$ nutrient solution was prepared with Seamax brand seaweed fertilizer and this solution was applied with spray 1 time every day from planting to harvesting (Table 2).

Table 2. Contents of Seamax seaweed (Ascophyllum nodosum) extract

\begin{tabular}{lclc}
\hline Contents (\%) & \multicolumn{3}{c}{ Contents (\%) } \\
\hline Organic matter & 47.5 & $\mathrm{~S}$ & 2.5 \\
$\mathrm{~N}$ & 0.75 & Fe & 0.004 \\
$\mathrm{P}$ & 0.02 & $\mathrm{~B}$ & 0.006 \\
$\mathrm{~K}$ & 14.9 & $\mathrm{Zn}$ & 0.006 \\
$\mathrm{Ca}$ & 0.3 & $\mathrm{Cu}$ & 0.0002 \\
$\mathrm{Mg}$ & 0.2 & Alginic acid & 5.5
\end{tabular}

In inorganic fertilizer applications, a nutrient solution (210 ppm N, 31 ppm P, 234 ppm K, 200 ppm Ca, 48 ppm Mg, 64 ppm S, 0.05 ppm Zn, 0.02 ppm Cu, 1.4 ppm Fe, 0.5 ppm Mn, $0.5 \mathrm{ppm} \mathrm{B}, 0.001 \mathrm{ppm} \mathrm{Mo}$ ) was prepared based on Hoagland and Arnon (1950), and this solution was applied with spray 1 time every day from planting to harvesting (Table 3).

The trials were carried out as three replications according to the randomized plots experimental design. The results were subjected to the variance analysis and differences were determined by using the $F$ test. The average values of the processes whose differences were determined were grouped according to the "HSD" significance test (JMP, 2007).

Table 3. Fertilizers used in inorganic solution

\begin{tabular}{lccc}
\hline Fertilizers & Quantity I $^{-1}$ & Fertilizers & Quantity g I $^{-1}$ \\
\hline $\mathrm{CaNO}_{3}$ & 0.45 & $\mathrm{KNO}_{3}$ & 0.51 \\
$\mathrm{MAP}\left(\mathrm{NH}_{4} \mathrm{H}_{2} \mathrm{PO}_{4}\right)$ & 0.12 & $\mathrm{MgSO}_{4}$ & 0.4 \\
$\mathrm{KSO}_{4}$ & 0.13 & Agromix & 0.2 \\
\hline
\end{tabular}

\section{RESULTS AND DISCUSSION}

Growth Parameters of Different Seed Densities

Whereas the highest green plant and dry grass yield values were obtained from $75 \mathrm{~g} \mathrm{~m}^{-2}$ applications (621.3 and 48.48, respectively, $\mathrm{P}<0.01)$, the lowest values were obtained from $25 \mathrm{~g} \mathrm{~m}^{-2}$ applications (160.2 and 16.86, respectively, $P<0.01)$. As the amount of seeds increases, the yield values of green plant and dry grass also increase as directly proportionate to this. While the highest dry matter rate and root length values were obtained from $25 \mathrm{~g} \mathrm{~m}^{-2}$ seed density applications ( 10.5 and 5.0, respectively, $P<0.01$ ), the lowest values were obtained from $75 \mathrm{~g} \mathrm{~m}^{-2}$ applications (7.8 and 3.0 , respectively, $P<0.01$ ). It was observed that as the seed density increased, root length values decreased. Any statistically significant difference could not found between seed densities in terms of plant height, emergence, and covering speed values (Table 4).

Table 4. Green plant yield, dry matter rate, dry grass yield, plant height, emergence, covering speed, and root length values of different seed densities

\begin{tabular}{|c|c|c|c|c|c|c|c|c|}
\hline \multicolumn{2}{|l|}{ Applications } & \multirow{2}{*}{$\begin{array}{c}\text { Green Plant } \\
\text { Yield }\left(\mathrm{g} \mathrm{m}^{-2}\right)\end{array}$} & \multirow{2}{*}{$\begin{array}{c}\text { Dry Matter } \\
\text { Rate (\%) }\end{array}$} & \multirow{2}{*}{$\begin{array}{c}\text { Dry Grass } \\
\text { Yield }\left(\mathrm{g} \mathrm{m}^{-2}\right) \\
16.86 \mathrm{C}\end{array}$} & \multirow{2}{*}{$\begin{array}{c}\begin{array}{c}\text { Plant } \\
\text { Height } \\
\text { (cm) }\end{array} \\
8.5\end{array}$} & \multirow{2}{*}{$\begin{array}{c}\text { Emergence } \\
\text { Speed } \\
\text { (day) }\end{array}$} & \multirow{2}{*}{$\begin{array}{c}\text { Covering } \\
\begin{array}{c}\text { Speed } \\
\text { (day) }\end{array} \\
7\end{array}$} & \multirow{2}{*}{$\begin{array}{c}\text { Root } \\
\text { Length }(\mathbf{c m})\end{array}$} \\
\hline Seed & 25 & & & & & & & \\
\hline \multirow{2}{*}{$\begin{array}{l}\text { Densities } \\
\mathrm{g} \mathrm{m}^{-2}\end{array}$} & 50 & 377.5 b & $8.8 \mathrm{~b}$ & $33.20 \mathrm{~b}$ & 8.6 & 5 & 7 & $3.5 \mathrm{~b}$ \\
\hline & 75 & $621.3 \mathrm{a}$ & $7.8 \mathrm{c}$ & $48.48 \mathrm{a}$ & 10.1 & 5 & 7 & $3.0 \mathrm{c}$ \\
\hline \multicolumn{2}{|l|}{ HSD } & $37.9 * *$ & $0.07 * *$ & $0.1^{* *}$ & Ns & Ns & Ns & $0.02 * *$ \\
\hline
\end{tabular}

HSD; Honesty significant difference, ${ }^{*} ; \mathrm{P}<0.05,{ }^{* *} ; \mathrm{P}<0.01, \mathrm{Ns} ;$ Not significant 
The highest overall appearance and tiller number values were obtained from $75 \mathrm{~g} \mathrm{~m}^{-2}$ applications (9 and 1444.3, respectively), while the lowest values were obtained from $25 \mathrm{~g} \mathrm{~m}^{-2}$ applications ( 3 and 622.1, respectively, $\mathrm{P}<0.01$ ). The highest shoot diameter and leaf blade width values were obtained from $25 \mathrm{~g} \mathrm{~m}^{-2}$ applications (0.6 and 1.2, respectively). The lowest values, on the other hand, were obtained from $75 \mathrm{~g} \mathrm{~m}^{-2}$ applications (0.4 and 0.8, respectively). Whereas the highest (114.6) index values were obtained from $75 \mathrm{~g} \mathrm{~m}^{-2}$ applications, the lowest values were obtained from 25 and $50 \mathrm{~g} \mathrm{~m}^{-2}$ applications (62.5 and 59.6, respectively), and they took place in the same statistical group (b) $(P<0.01)$. In terms of leaf blade length values, any statistically significant difference could not found between seed densities (Table 5).

In a study conducted using Lolium perenne with seed densities of $10-100 \mathrm{~g} \mathrm{~m}^{-2}$ in Bingley, England, Shildrick (1984) found that 5 months after planting, the tiller number in one $\mathrm{dm}^{2}$ ranged from 125-500. In other words, a 10times difference in the seed density led to a 4-times difference in the tiller density within 5 months. According to the same researcher, in studies conducted with Poa pratensis in California, the 8-time difference in seed density did not make a noticeable difference in tiller density after 8 months (Zorer et al., 2010). Oral and Açıkgöz (1999), used seed densities, from a standard mixture, ranging from 10$100 \mathrm{~g} \mathrm{~m}^{-2}$ at intervals of 10 grams. In the research, the effect of seed densities on covering speed was found to be significant in observations made within 45 days after planting, and it was seen that as seed density increased, the covering speed also increased. Zorer et al. (2010), were conducted research to determine the appropriate seed density for grass areas to be installed in the Van region, very fast covering was observed in plantings carried out with a high amount of seed, while the covering speed was determined to be slow in plantings performed with low amounts of seed. In the same study, it was found that a high seed density initially positively affects the quality of grass, but a decrease in grass quality was seen due to competition between plants in later periods. On the other hand, a problem was experienced in low seed densities in terms of fighting weeds, and a better grass quality was achieved after the planting performed by using mediumlevel seed density (Zorer et al., 2010).

In terms of seed densities, there are very large differences in the literature. The seed densities vary according to the seed size of the used species, the condition of the seed bed, climatic conditions, and the growth form of the plant to be planted (Açıkgöz, 1994). In studies, it has been reported that the seed density can range between $2.5-5 \mathrm{~g} \mathrm{~m}^{-2}$ in small seed species and between $20-70 \mathrm{~g} \mathrm{~m}^{-2}$ in large seed species (Avcıoğlu, 1997; Kuşvuran, 2009).

In their study conducted to determine the optimal seed densities for Poa pratensis L grass varieties (Kentucky bluegrass (KBG), P. supina Schrad. (Supina bluegrass (SBG)), Lolium perenne L. (Perennial ryegrass (PR)), ve Festuca arundinacea L. (Tall fescue (TS)] in a soilless growing environment called ekomat produced from wood fibers, Sorochan and Rogers (1995) used 1, 2, and 4 times of the seed densities ( $7.5 \mathrm{~g} \mathrm{~m}^{-2}$ for KGB and SBG, $40 \mathrm{~g} \mathrm{~m}^{-2}$ for PR and TS) used in the conventional production performed with soil. After two months, whereas the highest (76.3\%) covering rate was obtained from PR, the lowest (19.2) covering rate was obtained from KBG. It was reported that as the seed densities increased, the covering rates also increased. As a result, they found the applications of Lolium perenne L. and 4-times seed density $\left(160 \mathrm{~g} \mathrm{~m}^{-2}\right)$ as recommendable (Sorochan and Rogers, 1995). It is assumed that the difference between the results obtained here and the results of our research is due to environmental conditions (controlled and field).

\section{Growth Parameters for Different Temperature Applications}

The highest green plant yield values were obtained from 25 and $30{ }^{\circ} \mathrm{C}$ temperature applications (377.5 and 400.5, respectively) and they took place in the same statistical Group (a) $(P<0.01)$. The lowest (316.2) green plant yield was obtained from $35{ }^{\circ} \mathrm{C}$ temperature applications. Whereas the highest (33.2) dry grass yield values were obtained from $25{ }^{\circ} \mathrm{C}$ temperature applications, the lowest (26.3) values were obtained from $35{ }^{\circ} \mathrm{C}$ temperature applications $(P<0.01)$. Any statistically significant differences could not found between temperature applications in terms of dry matter rate, plant height, emergence, covering speed, and root length values (Table 6).

Table 5. Overall appearance, shoot diameter, tiller number, leaf blade length, leaf blade width and index values of different seed densities

\begin{tabular}{|c|c|c|c|c|c|c|c|}
\hline \multicolumn{2}{|c|}{ Applications } & $\begin{array}{c}\text { Overall } \\
\text { Appearance } \\
(1-9) \\
\end{array}$ & $\begin{array}{c}\text { Shoot } \\
\text { Diameter } \\
(\mathrm{mm}) \\
\end{array}$ & $\begin{array}{c}\text { Tiller } \\
\text { Number } \\
\text { (number } \mathrm{cm}^{-2} \text { ) }\end{array}$ & $\begin{array}{c}\text { Leaf Blade } \\
\text { Length } \\
(\mathrm{cm})\end{array}$ & $\begin{array}{c}\text { Leaf Blade } \\
\text { Width } \\
(\mathrm{mm})\end{array}$ & $\begin{array}{c}\text { Index } \\
\text { Values }\end{array}$ \\
\hline \multirow{3}{*}{$\begin{array}{l}\text { Seed } \\
\text { Densities } \\
\mathrm{g} \mathrm{m}^{-2}\end{array}$} & 25 & $3 c$ & $0.60 \mathrm{a}$ & $622.1 \mathrm{c}$ & 7.5 & $1.2 \mathrm{a}$ & $62.5 \mathrm{~b}$ \\
\hline & $50^{\circ}$ & $8 \mathrm{~b}$ & $0.51 \mathrm{~b}$ & $833.2 b$ & 6.3 & $1.06 \mathrm{~b}$ & $59.6 \mathrm{~b}$ \\
\hline & 75 & $9 a$ & $0.40 \mathrm{c}$ & $1444.3 \mathrm{a}$ & 9.1 & $0.8 \mathrm{c}$ & $114.6 \mathrm{a}$ \\
\hline \multicolumn{2}{|c|}{ HSD } & $0.001^{* *}$ & $0.01^{* *}$ & $90.75 * *$ & Ns & $0.06 * *$ & $27.62 * *$ \\
\hline
\end{tabular}

HSD; Honesty significant difference, ${ }^{*} ; \mathrm{P}<0.05$, $^{* *}$; P $<0.01, \mathrm{Ns}$; Not significant 
Table 6. Green plant yield, dry matter rate, dry grass yield, plant height, emergence, covering speed, and root length values for different temperatures

\begin{tabular}{|c|c|c|c|c|c|c|c|c|}
\hline Applications & & $\begin{array}{c}\text { Green Plant } \\
\text { Yield } \\
\left(\mathrm{g} \mathrm{m}^{-2}\right)\end{array}$ & $\begin{array}{l}\text { Dry Matter } \\
\text { Yield } \\
\text { (\%) }\end{array}$ & $\begin{array}{c}\text { Dry Grass } \\
\text { Yield } \\
\left(\mathrm{g} \mathrm{m}^{-2}\right)\end{array}$ & $\begin{array}{l}\text { Plant } \\
\text { Height } \\
\text { (cm) }\end{array}$ & $\begin{array}{c}\text { Emergence } \\
\text { Speed } \\
\text { (day) }\end{array}$ & $\begin{array}{c}\text { Covering } \\
\text { Speed } \\
\text { (day) }\end{array}$ & $\begin{array}{c}\text { Root } \\
\text { Length } \\
\text { (cm) }\end{array}$ \\
\hline \multirow{3}{*}{ Temperatures ${ }^{\circ} \mathrm{C}$} & 25 & $377.5 \mathrm{a}$ & 8.8 & $33.2 \mathrm{a}$ & 8.6 & 5 & 7 & 3.5 \\
\hline & 30 & $400.5 \mathrm{a}$ & 7.7 & $31.0 \mathrm{~b}$ & 8.2 & 5 & 7 & 3.3 \\
\hline & 35 & $316.2 \mathrm{~b}$ & 8.3 & $26.3 \mathrm{c}$ & 7.2 & 4 & 6 & 3.0 \\
\hline HSD & & $32.37^{* *}$ & Ns & $0.01 * *$ & Ns & Ns & Ns & Ns \\
\hline
\end{tabular}

HSD; Honesty significant difference, ${ }^{*}$; P <0.05, ${ }^{* *}$; P $<0.01$, Ns; Not significant

While the highest shoot diameter and leaf blade width values were obtained from $25{ }^{\circ} \mathrm{C}$ temperature applications (0.51 and 1.06, respectively), the lowest values were obtained from $35{ }^{\circ} \mathrm{C}$ temperature applications (0.43 and 0.92 , respectively, $p<0.05)$. The highest tiller number values were obtained from temperature applications of 25 and 30 ${ }^{\circ} \mathrm{C}$ (833.2 and 888.8, respectively) and they were in the same statistical group (a) $(P<0.01)$. The lowest (722.1) tiller number values, on the other hand, were obtained from 35 ${ }^{\circ} \mathrm{C}$ temperature applications $(\mathrm{P}<0.01)$. No statistically significant differences were found between temperature applications in terms of overall appearance, leaf blade length, and index values (Table 7).

In their study, Salehi et al. (2008) stated that the optimal soil temperature for the growth of Bermuda (warm climate) grass is between 24 and $29{ }^{\circ} \mathrm{C}$. Avcioglu (1997), reported that cool-climate gramineae grass needs $10-18^{\circ} \mathrm{C}$ in terms of root growth and $15-25^{\circ} \mathrm{C}$ in terms of above-ground growth and development. In addition, he stated that the excess of number of shoots (density value) in the unit area in grass plants is important in terms of preventing unwanted weeds, completely covering the area, and creating green vegetation. Similar results have been also expressed by other researchers (Yoon et al., 1985; Lin et al., 2018).

\section{Growth Parameters for Different Fertilizer Applications}

The highest root length values were obtained from Sw and In applications (4.3 and 4.3, respectively) and they took place in the same statistical group (a) $(P<0.01)$. On the other hand, the lowest (3.5) root length values were obtained from Co applications. The effects of different fertilization applications on green plant yield, dry matter rate, dry grass yield, plant length, emergence, and covering speed were not statistically significant (Table 8).

Whereas the highest (0.6) shoot diameter values were obtained from In applications, the lowest (0.51) values were obtained from Co applications $(p<0.05)$. Any statistically significant difference was not found between fertilization applications in terms of overall appearance, tiller number, length and width of leaf blade, and index values (Table 9).

Table 7. Overall appearance, shoot diameter, tiller number, leaf blade length, leaf blade width, and index values for different temperatures

\begin{tabular}{|c|c|c|c|c|c|c|c|}
\hline Applications & & $\begin{array}{c}\text { Overall } \\
\text { Appearance } \\
(1-9)\end{array}$ & $\begin{array}{c}\text { Shoot } \\
\text { Diameter } \\
(\mathrm{mm})\end{array}$ & $\begin{array}{c}\text { Tiller } \\
\text { Number } \\
\text { (number } \mathrm{cm}^{-2} \text { ) }\end{array}$ & $\begin{array}{l}\text { Leaf Blade } \\
\text { Length } \\
(\mathrm{cm})\end{array}$ & $\begin{array}{l}\text { Leaf Blade } \\
\text { Width } \\
\text { (mm) }\end{array}$ & $\begin{array}{l}\text { Index } \\
\text { Values }\end{array}$ \\
\hline \multirow{3}{*}{ Temperatures ${ }^{\circ} \mathrm{C}$} & 25 & 9 & $0.51 \mathrm{a}$ & $833.2 \mathrm{a}$ & 6.3 & $1.06 \mathrm{a}$ & 59.6 \\
\hline & 30 & 9 & $0.48 a b$ & $888.8 \mathrm{a}$ & 6.6 & $0.99 a b$ & 67.0 \\
\hline & 35 & 8 & $0.43 \mathrm{~b}$ & $722.1 \mathrm{~b}$ & 5.8 & $0.92 b$ & 62.8 \\
\hline HSD & & Ns & $0.04^{*}$ & $72.2^{* *}$ & Ns & $0.07^{*}$ & Ns \\
\hline
\end{tabular}

HSD; Honesty significant difference, ${ }^{*} ; \mathrm{P}<0.05,{ }^{* *} ; \mathrm{P}<0.01, \mathrm{Ns} ;$ Not significant

Table 8. Green plant yield, dry matter rate, dry grass yield, plant length, emergence, covering speed, and root length values for different fertilization applications

\begin{tabular}{|c|c|c|c|c|c|c|c|c|}
\hline Applications & & $\begin{array}{c}\text { Green Plant } \\
\text { Yield } \\
\left(\mathrm{g} \mathrm{m}^{-2}\right)\end{array}$ & $\begin{array}{c}\text { Dry Matter } \\
\text { Rate } \\
\text { (\%) }\end{array}$ & $\begin{array}{c}\text { Dry Grass } \\
\text { Yield } \\
\left(\mathrm{g} \mathrm{m}^{-2}\right)\end{array}$ & $\begin{array}{c}\text { Plant } \\
\text { Height } \\
\text { (cm) }\end{array}$ & $\begin{array}{c}\text { Emergence } \\
\text { Speed } \\
\text { (day) }\end{array}$ & $\begin{array}{c}\text { Covering } \\
\text { Speed } \\
\text { (day) }\end{array}$ & $\begin{array}{l}\text { Root } \\
\text { Length } \\
\text { (cm) }\end{array}$ \\
\hline \multirow{3}{*}{ Fertilization } & Co & 377.9 & 8.8 & 33.20 & 8.6 & 5 & 7 & $3.5 \mathrm{~b}$ \\
\hline & Sw & 404.4 & 8.4 & 34.25 & 8.8 & 5 & 7 & $4.3 \mathrm{a}$ \\
\hline & In & 412.3 & 7.7 & 34.78 & 9.5 & 5 & 7 & $4.3 \mathrm{a}$ \\
\hline HSD & & Ns & $\mathrm{Ns}$ & Ns & $\mathrm{Ns}$ & Ns & Ns & $0.41 * *$ \\
\hline
\end{tabular}

HSD; Honesty significant difference, *; $\mathrm{P}<0.05, * * ; \mathrm{P}<0.01$, Ns; Not significant 
Effects of Different Seed Density, Temperature and Fertilization Applications

on Some Growth Parameters in Soilless Roll Sod Production

Table 9. Overall appearance, shoot diameter, tiller number, leaf blade length, leaf blade width, and index values for different fertilization applications

\begin{tabular}{|c|c|c|c|c|c|c|c|}
\hline Applications & & $\begin{array}{c}\text { Overall } \\
\text { Appearance } \\
(1-9)\end{array}$ & $\begin{array}{c}\text { Shoot } \\
\text { Diameter } \\
(\mathrm{mm})\end{array}$ & $\begin{array}{c}\text { Tiller } \\
\text { Number } \\
\text { (number } \mathrm{cm}^{-2} \text { ) }\end{array}$ & $\begin{array}{l}\text { Leaf Blade } \\
\text { Length } \\
\text { (cm) }\end{array}$ & $\begin{array}{l}\text { Leaf Blade } \\
\text { Width } \\
\text { (mm) }\end{array}$ & $\begin{array}{c}\text { Index } \\
\text { Values }\end{array}$ \\
\hline \multirow{3}{*}{ Fertilization } & Co & 9 & $0.51 \mathrm{~b}$ & 833.2 & 6.3 & 1.0 & 59.6 \\
\hline & Sw & 9 & $0.56 \mathrm{ab}$ & 888.8 & 6.8 & 1.1 & 59.5 \\
\hline & In & 9 & $0.6 \mathrm{a}$ & 944.3 & 7.5 & 1.1 & 63.5 \\
\hline \multicolumn{2}{|l|}{ HSD } & Ns & $0.01 *$ & Ns & Ns & Ns & Ns \\
\hline
\end{tabular}

HSD; Honesty significant difference, ${ }^{*}$; P <0.05, ${ }^{* *}$; P <0.01, Ns; Not significant

Nitrogen has a positive effect on many different characteristics of grass plants, such as the shoot density, color, resistance to diseases, and the regeneration ability. Usually, color is used as an indicator in nitrogen fertilization. Therefore, the amount and application time of nitrogen fertilization play an important role in the maintenance of grass areas (Oral and Açıkgöz, 1999; Salman and Avcıoğlu, 2010). In their study conducted to determine the appropriate nitrogen fertilizer application times in grass areas, Zorer et al. (2003) reported that if nitrogen fertilization was not performed, there would be significant decreases in the growth and quality of grass areas over time. Researchers reported that green grass yield increased in different rates after nitrogen fertilizer applications. In their study conducted to determine the optimal fertilizer (organic and inorganic) and pure $\mathrm{N}$ rates $(1.2,2.4$, and $4.8 \mathrm{~g}$ $\mathrm{m}^{-2}$ ) for Poa pratensis L. grass varieties (Kentucky bluegrass (KBG), P. supina Schrad. (Supina bluegrass (SBG)), Lolium perenne L. (Perennial ryegrass (PR)), ve Festuca arundinacea L. (Tall fescue (TS) in a soilless growing environment called ekomat produced from wood fibers, Sorochan and Rogers (1995) found organic and $2.5 \mathrm{~g} \mathrm{~m}^{-2}$ pure $\mathrm{N}$ amounts to be recommendable. It is assumed that the difference between the results obtained here and the results of our research is due to the growing period and environmental conditions (controlled and field).

\section{CONCLUSIONS}

According to the research results, the highest green plant yields and tiller number values were obtained from the seed density of $75 \mathrm{~g} \mathrm{~m}^{-2}$ and the 25 and $30{ }^{\circ} \mathrm{C}$ temperature applications. The highest dry matter rate values were obtained from $25 \mathrm{~g} \mathrm{~m}^{-2}$ seed density applications, while the highest dry grass yield values were obtained from $75 \mathrm{~g} \mathrm{~m}^{-2}$ seed density and $25{ }^{\circ} \mathrm{C}$ temperature applications. While the highest root length values were obtained from $25 \mathrm{~g} \mathrm{~m}^{-2}$ seed density and Sw and In fertilization applications, the best overall appearance and index values were obtained from $75 \mathrm{~g} \mathrm{~m}^{-2}$ seed density applications. The highest shoot diameter values were obtained from $25 \mathrm{~g} \mathrm{~m}^{-2}$ seed density, $25{ }^{\circ} \mathrm{C}$ temperature, and In fertilization applications, while the highest leaf blade width values were obtained from 25 $\mathrm{g} \mathrm{m}^{-2}$ seed density and $25^{\circ} \mathrm{C}$ temperature applications.

When research results are evaluated by taking into account the highest overall appearance and green plant yield values together, it is observed that $75 \mathrm{~g} \mathrm{~m}^{-2}$ seed density and 25 and $30^{\circ} \mathrm{C}$ temperature applications are in recommendable qualification. For future studies to be conducted on the subject, it is considered useful to include different growing times and land applications in the studies.

\section{ACKNOWLEDGMENT}

The author is thankful for the support extended by Selçuk University Scientific Research Projects (BAP). This research consists of a part of the project numbered 17401185.

\section{REFERENCES}

Açıkgöz E (1994) Çim Alanlar Yapım ve Bakım Tekniği. Uludağ Üniversitesi Ziraat Fakültesi, Bursa.

Alshammary S, Qian Y, Wallner S (2004) Growth response of four turfgrass species to salinity. Agricultural Water Management, 66 (2): 97-111.

Avcıoğlu R (1997) Çim Tekniği, Yeşil Alanların Ekimi Dikimi ve Bakımı. Ege Üniversitesi Matbaası, Bornova-İzmir.

Carrow RN, Waddington DV, Rieke PE (2001) Turfgrass Soil Fertility \& Chemical Problems: Assessment and Management. John Wiley \& Sons.

Carrow RN., Krum JM, Flitcroft I, Cline V (2010) Precision turfgrass management: challenges and field applications for mapping turfgrass soil and stress. Precision Agriculture, 11(2): 115-134.

Casimaty BG, Neylan J, Beard JB (1993) Effects of Removal by Post-Harvest Hydraulic Washing on Sod Transplant Rooting of Kentucky Blue Grass-Perennial Rye Grass Polystand and Creeping Bentgrass Monostand. In Corrow, R.N., Christians, N.E., Sherman, R.C. (Ed.) Int., Tur-fgrass Soc., Res., J., 7: 850-856.

Karaşahin M (2020) Topraksız rulo çim üretimi ve avantajları. HarmanTIME, 89: 94-96.

Kuşvuran A (2009) Çukurova Koşullarına Uygun Çim Tür ve Karışımlarının Belirlenmesi ve Performanslarının Saptanması. Doktora Tezi, Çukurova Üniversitesi, Fen Bilimleri Enstitüsü, Tarla Bitkileri Anabilim Dalı, Adana.

Lin J, Hua X, Peng X, Dong B, Yan X (2018) Germination Responses of Ryegrass (Annual vs. Perennial) Seed to the Interactive Effects of Temperature and Salt-Alkali 
Stress. Front. Plant Sci., 9:1458. doi: Shildrick J (1984) Turfgrass Manual. The sports Turf 10.3389/fpls.2018.01458 Research Institue Publ., BBingley, England.

Oral N, Açıkgöz E (1999) Bursa Bölgesinde Tesis Edilecek Çim Alanları İçin Tohum Karışımları, Ekim Oranları ve Azotlu Gübre Uygulamaları Üzerinde Araştırmalar. Türkiye 3. Tarla Bitkileri Kongresi Bildirileri, (pp.155), 15-18 Kasım 1999, Adana.

Orçun E (1979). Özel Bahçe Mimarisi (Çim Sahaları Tesis ve Bakım Tekniği). Ege Üniversitesi Ziraat Fakültesi Yayınları No: 152, Bornova, İzmir.

Özad E (2010) Organik Atıklardan Rulo Çim Yetiştirme Ortamının Hazırlanması. Yüksek Lisans Tezi, Sakarya Üniversitesi Fen Bilimleri Enstitüsü, Çevre Mühendisliği Anabilim Dalı, Sakarya.

Salehi MR, Ashiri F, Salehi H (2008) Effect of Different Ethanol Concentrations on Seed Germination of Three Turfgrass. Advances in Natural and Applied Sciences, 2(1): 6-9.

Salman A, Avcıoğlu R (2010) Bazı Serin Iklim Çim Bitkilerinin Farklı Gübre Dozlarındaki Yeşil Alan Performansları. Ege Üniv. Ziraat Fak. Dergisi, 47 (3): 309-319.

Sorochan JC, Rogers JN (1995) Soilless Sod Production Using Ecomat. LT, 3:9.

Turgeon AJ (2002) Turfgrass Management. 6th ed. Prentice Hall Inc., NJ. U.S.A

Yoon SY, Murayama S, Kosaka S (1985) Studies on temperature responses of grasses. 2. Comparison of germination of temperate and tropical grasses in various temperature conditions. Journal of the Yamagata Agriculture and Forestry Society, 42, 21-25.

Zorer Ş, Hosaflıoğlu i, Yılmaz iH (2003) Çim Alanlarında Uygun Azotlu Gübre Uygulama Zamanlarının Belirlenmesi. Yüzüncü Yıl Üniversitesi, Ziraat Fakültesi, Tarım Bilimleri Dergisi, 14(1): 27-34.

Zorer ŞÇ, Andiç N, Yılmaz ï (2010) Van Bölgesinde Tesis Edilecek Çim Alanları İçin Uygun Tohumluk Miktarının Saptanması. Yüzüncü Yıl Üniversitesi, Ziraat Fakültesi, Tarım Bilimleri Dergisi, 20 (1):16-25. 
